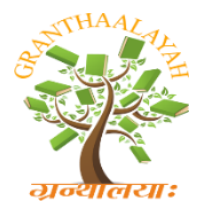

\author{
INTERNATIONAL JOURNAL OF RESEARCH \\ GRANTHAALAYAH \\ A knowledge Repository
}

Social

\title{
KIAI LEADERSHIP IN INTEGRATING ISLAMIC SCIENCE AND SCIENCE TOWARDS IDEAL PLANNERS (CASE STUDY AT SUMENEP ISLAMIC BOARDING SCHOOL RAUDLATUL IMAN)
}

\author{
FATHORRAHMAN *1 \\ ${ }^{* 1}$ Raudlatul Iman College of Da'wah Science (STIDAR) Sumenep, Doctoral Program in \\ Management of Islamic Education, The State Institute for Islamic Studies Jember
}

\begin{abstract}
This research was carried out because of the anxiety of researchers seeing islamic boarding school as indigenous increasingly excluded from the competitive arena of modern education. Islamic boarding schools are increasingly not in demand by students because they do not issue diplomas such as formal schools. And the most important thing seen from the islamic boarding school at this time, the fact that students are less interested in Islamic scholarship, especially the yellow book, the legacy of salaf scholars, the students are more interested in science. For researchers, this problem must be studied and find a solution so that the islamic boarding school can return to its line of printing Ulama, ulama who are knowledgeable in Islamic science and science. The Raudlatul Iman Islamic Boarding School in Sumenep which was used as the object of this study experienced the things described above, where there was an imbalance in applying scientific integration of Islamic sciences and science. student are more interested in learning science than Islamic science, especially the yellow book. While the findings of the data of researchers in the field show, to anticipate and prevent the negative implications of the failure of scientific integration at the Raudlatul Iman islamic boarding school, the kiai made a breakthrough by reforming the islamic boarding school curriculum and organizing the islamic boarding school organization. This was done so that the islamic boarding school he managed would become a future islamic boarding school.
\end{abstract}

Keywords: Leadership; Kiai; Islamic Boarding School; Scientific Integration; and Curriculum.

Cite This Article: Fathorrahman. (2018). "KIAI LEADERSHIP IN INTEGRATING ISLAMIC SCIENCE AND SCIENCE TOWARDS IDEAL PLANNERS (CASE STUDY AT SUMENEP ISLAMIC BOARDING SCHOOL RAUDLATUL IMAN)." International Journal of Research Granthaalayah, 6(10), 14-24. https://doi.org/10.29121/granthaalayah.v6.i10.2018.1157.

\section{Introduction}

The task of improving the quality of human resources in creating the younger generation is not only played by the government through formal schools and Madrasas, on the other hand external elements such as Islamic boarding schools as the oldest Islamic education institutions in Indonesia 
also have a big role in educating the lives of the nation (Suheri: 2017). Islamic boarding school is a noble education in beloved Indonesia. This institution has been proven to be able to make scientists or scholars and kiai national and even international caliber, for example at the beginning of its development. There are names such as Sunan Giri, Sunan Bonang, Sunan Kalijaga, and names born like Syaikh Nawawi Al-Bantani, Shaykh Muhammad Kholil Bangkalan, KH. M. Hasyim Asy'ari, KH. Wahab Hazbullah, KH. Bisyri Syamsuri, KH. Wahid Hasyim, KH. Abdurrahman Wahid, and KH. Aqil Siraj said. They are boarding schools that are role models and idols of Indonesian society (Jamal Ma'mur Asmani, 2011: 2). These figures are from islamic boarding school in their day, which is better known as traditional islamic boarding school, a islamic boarding school which only focuses on Islamic scientific experience. This happens for one reason, namely because the environment demands it. In other words, society and the environment demand the availability of educational institutions that offer Islamic clothing. So, traditional islamic boarding school cannot be separated from environmental factors and community needs in Islamic religious understanding.

But with the times, Islamic boarding schools are required must transform from traditional to modern forms as well as to adapt to the time, and also the needs, as well as the development of science and technology. Islamic boarding school also respond quickly by using general sciences, not only that, islamic boarding school also provides training and various skills. Islamic boarding schools have transformed with a new format into modern boarding schools while maintaining their identity as Islamic education. Thus, the islamic boarding school currently has the scientific dualism taught in it, namely Islamic knowledge and general knowledge. Automatically, too, the curriculum is a curriculum that integrates the two scientific disciplines. Therefore, some pesantren integrate curricula originating from the government and a pure curriculum from the pesantren with the aim to equip students not only tafaqquh fi al din but also have the ability to general knowledge (Suheri:2018)

Initially, the integration of the two sciences conducted by islamic boarding school was encouraging news, because it meant that islamic boarding school were welcome towards progress or what is often called modernization, but gradually but surely, scientific integration became a dilemma for the pantantren, because the tradition of mastery or deepening of Islamic sciences was decreasing, even worse there are some islamic boarding school such as dormitories because the students who study in them are not in order to explore Islamic scholarship, but for formal schools in the islamic boarding school. Thus, religious education activities held by islamic boarding school are only additional activities for the islamic boarding school students. The students tend to focus only on general subjects (science) rather than Islamic lessons. The above fact is a factor in the decline of islamic boarding school in making Muslim scholars. Islamic boarding schools emphasize too much on general knowledge and the speed of technology, so that they forget about their sacred task in producing the output of scholars or scientists (Jamal Ma'mur Asmani, 2011: 17).

Based on the above facts, the author wants to say that scientific integration in islamic boarding school fails a little because most islamic boarding school cannot harmonize and harmonize and balance Islamic scholarship and science knowledge. What happens is the imbalance between the theory of integration and curriculum integration (which is the initial ideal) with practice in the field (teaching and learning). As a result, the tradition of the yellow book increasingly eroded by the 
flow of modernization. This is what must be anticipated quickly before it becomes chronic, which can endanger the existence of islamic boarding school, by finding alternative solutions to change the negative impression of the islamic boarding school above. One way to maintain the existence of islamic boarding school is by returning the position of Islamic education to what is reasonable, or in other words, restoring Islamic education to the islamic boarding school itself (Abd. Halim Soebahar, 2013: 36). What is meant by Islamic education, is education that truly serves students in exploring Islamic scholarship, as is done by past Islamic boarding schools. The role of kiai as founders, owners, kings and caregivers of islamic boarding school is very important in finding solutions to this problem. Kiai who initiate or initiate efforts to restore the existence of islamic boarding school to their original foundation.

The reality above is the basic assumption why this research is urgent. The researcher will analyze the extent of the islamic boarding school (the role of the kiai) in integrating scientific dualism (Islamic science and science) so that the effort will dismiss the dichotomy between the two sciences. In addition, the extent of the leadership role of the kiai in responding to the implications of curriculum integration within their islamic boarding school. This is closely related to the kiai's strategy to answer all the problems above. And in the end, this study wanted to find out the results of the efforts of the kiai above in bringing their islamic boarding school into ideal and future islamic boarding school.

Researchers make Raudlatul Iman Islamic Boarding School as the object of their research, a quite large islamic boarding school in Sumenep. Scientific reasons why researchers make Raudlatul Iman Islamic Boarding Schools because these islamic boarding school experience problems with the entry of general sciences into their curriculum. The problem is that researchers see from the initial observations made by researchers and from the talk of researchers with one of the caregivers of the Islamic boarding school Rudlatul Iman (interview with Sahli Hamid Saturday, September 15, 2018).

\section{Materials and Methods}

This research is field research. Therefore, the data collected for this paper was obtained from the field. Because this includes field research, then in the search for data, researchers must be present in the field because researchers are the main research instrument that must be present directly into the field in the data collection process. Researchers in searching the data in the field, be careful and careful. These two things were revealed when the researcher communicated with all informants, especially with key informants in order to create an atmosphere that supports success in the data collection process.

This study uses a qualitative approach with the reason, first, what is studied is the meaning of one's actions, in this context the leadership of the kiai in managing the islamic boarding school they lead. Secondly, in its communication with social life, a person (kiai) has the right strategy to act, so it requires a sufficiently deep study of a phenomenon. Third, qualitative research provides an opportunity to examine phenomena holistically, so that in the context of this research, a qualitative approach is very appropriate to be used (Ali Hasan Siswanto, 2014: 13). 
Data sources used in this study are primary and secondary sources. Primary sources are data sources that directly provide data to data collectors, namely subjects or key informants. While secondary sources are sources that do not directly provide data to data collectors, for example through other people (Sugiyono, 2009: 225). Meanwhile, the selection of informants was carried out in the following ways: (1) purposive sampling technique, this technique was used to direct the data collection process according to the needs through the selection of informants who really mastered the information and problems that were in accordance with this research; and (2) snowball technique, a snowball technique, is used to search information continuously from one informant to another, so that the data obtained is more and more profound (Sugiyono, 2009: 103). In the process of data collection, this study uses several data collection techniques, namely indepth interviews and participant observation (Sugiyono, 2009: 234). Meanwhile, in analyzing the data, using data analysis techniques developed by Miles and Huberman. Through this model, data analysis activities can be carried out in three stages, including, first, data reduction, this is done because researchers realize that the data obtained from the field is quite large, complex, and complex. For this reason, it is necessary to immediately analyze the data through data reduction. Second, presenting data. According to Miles and Huberman the presentation of the data is intended to find meaningful patterns and provide the possibility of drawing conclusions and taking action. Data presentation is also intended to find a meaning from the data obtained, then compiled systematically. Third, drawing conclusions from the data obtained during data collection and after data collection (Sugiyono, 2009: 249).

\section{Results and Discussions}

\section{Results}

Raudlatul Iman Islamic Boarding School was founded in 1950, initiated by KH. Ibrahim, located in Gadu Village west of Ganding Sumenep Regency. Raudlatul Iman Islamic Boarding School originated from the wishes of the people around Gadu Barat and the people from neighboring villages to place their children in Kiai Ibrahim who were known for their pious and tawadhu. To realize this desire, the community worked together to establish a small mosque as the starting place for teaching and learning activities in the Qur'an and prayer. Not long from that, because the students were booming, then Kiai Ibrahim's desire to establish a islamic boarding school arose. In the establishment of this islamic boarding school, Kiai Ibrahim again received assistance from the community in the form of energy and material. The result of this joint work then established a boarding school named Islamic boarding school Raudlatul Iman, coinciding in 1950 (Sidki Hamid, interview, 18 September 2018).

Beginning from its establishment until 1963, Raudlatul Iman islamic boarding school adopted a salaf system, where the curriculum was only in the form of Islamic lessons. The teaching methods used are memorization, lecture, bandongan, and sorogan methods. Then in 1963, the Raudlatul Iman Islamic Boarding School progressed because this year, it established the Islamic Elementary School at the encouragement of the community and several kiai from other islamic boarding school. Thus, since the establishment of Islamic Elementary School this islamic boarding school began to recognize classical systems. And apparently, MI is the forerunner and foundation of the development of other formal education in the future. At present, the Raudlatul Iman Islamic Boarding School already has formal education institutions from the lowest to tertiary institutions, namely early childhood education, playground, Islamic Elementary School, islamic junior high 
school, Islamic senior high school, Vocational Schools, and the Raudlatul Iman College of Da'wah (STIDAR) (Sidki Hamid, interview, 18 September 2018) Furthermore, how is scientific integration in Raudlatul Iman Islamic Boarding School, the following explanation.

The integration of the science of religion and non-religion in the Raudlatul Iman islamic boarding school as a real skill that this islamic boarding school does not turn a blind eye to change. Scientific integration or can be called the integration of religious and non-religious science curricula in this islamic boarding school is intended to answer the development of science and technology, the demands of society, and the demands of the times. The era of modernization and globalization today is rolling fast forcing islamic boarding school to respond so that their existence is maintained and not swallowed up by the times. In addition to the above reasons, scientific integration carried out by islamic boarding school to destroy Western efforts that dichotomize religious and nonreligious sciences, because according to the Western claim of religious knowledge is not scientificirrational and can confuse and make someone stupid, while science is claimed as modern science bring progress (Mulyadhi Kartanegara, 2005: 20; Suheri:2018)). The efforts made by this islamic boarding school are merely to erase the scientific dichotomy as explained above. Because the islamic boarding school has the belief that the various existing and developing sciences, both religious and non-religious, are actually one source, namely from Allah. Mulyadhi Kartanegara emphasized that religion and science are based on God, because he is the source of truth (science). This problem, if elaborated in detail, we will find an explanation that God is one of the basic principles of Islamic teachings, and in our concern for the integration of science in islamic boarding school, has become the main principles of the principles of Islamic epistemology, so that he also becomes the principle from the integration of human knowledge (Mulyadhi Kartanegara, 2005: 32).

The principle of oneness of God (the principle of monotheism) according to Ibn Sina is to have two meanings, namely the form of al-obligatory and mumkin al-wujud. The form of al-obligatory that is meant here is that the wajud of Allah is obligatory, its form becomes obligatory without requiring any intermediary, nor does it rely on anything, other than that, essence cannot be separated from being, both are the same, this being (Allah) does not begin nor end (Sirajuddin Zar, 2004: 96).

Ibn Sina in proving the existence of Allah, does not need to take one of his creatures, or in other words, his proof is not based on Allah's creatures, but directly on Allah himself, as a form of alobligatory. This universe is mumkin al-wujud - whose existence requires illat. This Illat which emits into form because its form is not from the substance. Allah to show its existence does not require proof from its creatures (Sirajuddin Zar, 2004: 97). The proof has been clearly described in the Qur'an, in Surat al-Fushshilat 53:

Meaning: We will show them the signs of our greatness in the universe and in themselves, so that it is clear to them that your god witnessed everything.

Finally, the researcher can conclude that the scientific integration of religious and non-religious sciences in the Raudlatul Iman Islamic Boarding School is based on the principle of monotheism, that is that Allah is one substance and everything other than it is from it or its creation, including in this case religious and non-religious sciences sourced from God. So actually, between the two 
there is no difference in sources, because both come from God. And to maintain scientific integration in islamic boarding school we must both recognize the validity or validity of various human experiences, ranging from the sensual to the spiritual (Mulyadhi Kartanegara, 2005: 43). Another reason, according to KH. Sahli Hamid, the dualism integration of science aims to make islamic boarding school like super markets, what is needed by students is only to take. With scientific integration, it is expected that islamic boarding school can balance students scholarship. So, students in addition to mastering religion also master science (Sahli Hamid, interview, Saturday, September 15 2018).

However, the ideals and spirit of scientific integration at the Raudlatul Iman Islamic Boarding School did not go smoothly and in accordance with expectations, because between the ideals and facts were uneven, more dominated by non-religious science. What happened at the Islamic Boarding School Raudlatul Iman, the students recently were more interested in learning science than religion. As a result, many students today cannot read the yellow book, the Salaf Islamic boarding school heritage book. Related to this problem, the researcher will examine it in the next discussion.

\section{Discussion}

Kiai's leadership in Integrating Islamic Science and Science at Raudlatul Iman Islamic Boarding School. There are several terms that need to be defined in this research, because for researchers this term is a keyword that will later be useful in the description for the description of this paper. These keywords include leadership, kiai, and islamic boarding school, a description of the three terms is as follows.

First, leadership. The definition of leadership is very much as many people as trying to limit the definition of the concept of leadership. But in general, leadership means the process / effort that is done by someone to influence the actions of others to reach mutual agreement, work together, and achieve common goals. Can also mean, someone who influences the interpretation of the behavior of his followers, activities to achieve goals, as well as maintaining communication and cooperative relationships and work of groups and or organizations (Veitzal Rivai Zainal and friends, 2017: 2). Therefore, the effort to influence what someone does to make it meaningful must be influenced, which involves others (Veitzal Rivai Zainal and friends, 2017: 2).

Almost the same as the definition above, Stoner and Wankel define leadership as a process of influencing activities related to the task of the group, so that group activities are in accordance with what is desired by the leader, also in accordance with the set plan (James AF Stoner and Charles Wankel, 1986: 42).

For that reason, not everyone can be a leader or run leadership, because the condition of being a leader is he has influence, because with him he can transform his influence on others. And related to this influence, Rivai Zainal stated that the influence of the leader is determined by his status, namely whether he is a formal leader or an informal leader. In this context, the kiai falls into the second category, informal leader (Veitzal Rivai Zainal and friends, 2017: 3). Whereas in Islam, leadership is very synonymous with the words khalifah, amir (plural umara words), and ulil amri. Of the three words, each has definitive implications, for example the word Caliph refers to formal 
and informal leaders, said Amir (Umara) very closely with the formal authorities / government, while the word ulil amri shows the meaning of pious Islamic leaders who can provide guidance and education in the community. In connection with the definition of leadership in an Islamic perspective, Rivai Zainal concluded, Islamic leadership was an activity of guiding, guiding, guiding, and showing in the right and true way of Allah to receive pleasure from him (Veitzal Rivai Zainal and friends, 2017: 6).

Second, the kiai, are the main teachers or educators in the islamic boarding school. So called because the kiai the first to provide lessons, guidance, and education to students in the islamic boarding school. In islamic boarding school, kiai are single and main figures who are highly honored and used as hasanah references by their students. This happens to the kiai, because the kiai has advantages in various things when compared to people other than him, such as wisdom, high morals, established worship, degree of closeness to Allah, and so on (Abd. Halim Soebahar, 2013: 38). Meanwhile, according to Zamakhsyari Dhofier, the kiai is the most essential element in the islamic boarding school, often referred to as the founder and owner. Because the kiai as the founder and owner, naturally the growth and progress of the islamic boarding school depends on the abilities of the kiai. Still according to Dhofier, the position of kiai is given by the community to someone who has high Islamic knowledge, owns and nurtures islamic boarding school, and teaches classical books to his students (Zamakhsyari Dhofier, 2011: 93).

The third, islamic boarding school, is a word that gets additional prefix pe and ends up being a islamic boarding school, which refers to the place where Islamic education is held. Abdurrahman Wahid, for example, called the islamic boarding school the place where students live (a place where students live). Meanwhile, according to M. Ridwan Nasir, in the Babun Suharto, islamic boarding school are Islamic educational institutions that provide teaching, learning (Islam) and developing and spreading the knowledge of Islam (Babun Suharto, 2018: 31). Meanwhile, according to Halim Soebahar the islamic boarding school is an Islamic educational institution, where the students live and study under the guidance of a kiai (Abd. Halim Soebahar, 2013: 41). After knowing the three definitions above, the discussion of this paper will continue to discuss the leadership of the kiai in integrating Islamic scholarship and science.

Borrowing Dhofier's language that islamic boarding school is a small kingdom owned by kiai. So called because the kiai are the founders, owners and caregivers of the islamic boarding school, so it is not excessive if the kiai is called that (Zamakhsyari Dhofier, 2011: 94). As the founder, owner and caregiver of the islamic boarding school, the kiai has the power and competence to bring the islamic boarding school he leads. The power and competence of the kiai, even the kiai have multi competencies, can influence the pattern and system of islamic boarding school education that he manages (Abd. Halim Soebahar, 2013: 2). In addition, the kiai has high charismatic and spiritual capital, so with these two things, his leadership at the islamic boarding school is very easy for him. If based on the explanation above, the leadership of the kiai in islamic boarding school has a lot of capital; capital as founder, owner, caregiver, religious knowledge capital and other sciences, charismatic capital, educators, and other capital. So with those capitals, kiai easily carry out their leadership functions in islamic boarding school. Seeing the facts above, as if facilitating the kiai in advancing the islamic boarding school, but when viewed from the facts on the ground, not many kiai can deliver their islamic boarding school to progress. In the context of this research, not many kiai have successfully integrated scientific dualism (religious and non-religious science) in a 
balanced manner. The proof, we can see from the islamic boarding school that incorporate science as part of its curriculum cannot balance the two scientific disciplines, so what happens in some semi-modern and modern islamic boarding school today is to dominate science over religious science.

At the Raudlatul Iman islamic boarding school itself, what happened was not much different from other islamic boarding school. This islamic boarding school experienced the same fate, where the majority of students in this islamic boarding school came and attended school in formal institutions managed by the Raudlatul Iman Islamic boarding school. The orientation of the students now is only to pursue a diploma, and to forget its sacred purpose, namely tafaqquh fiddin, as a result of this reality it is not difficult to find students who are unable to read the yellow book. Apparently, students today are more likely to like science than religion. According to some students, if learning science in the future will be bright, if only learning the science of religion the future will be blurred. Why is that, because studying in a formal school if you graduate you will get a diploma while from the islamic boarding school if you have graduated you don't get a diploma. This diploma will later be used to find work (Sidqi Hamid, interview, Saturday, September 16, 2018).

The implications of the integration of religious and non-religious curricula at the Raudlatul Iman Islamic Boarding School have a negative effect, which is to make this islamic boarding school lose its prestige as an Islamic educational institution - which incidentally provides teaching and learning about Islamic teachings and the doctrine of Islamic values. The glory of the previous islamic boarding school, which prioritized the mastery of the yellow book, has now faded, since the implementation of scientific integration. In fact, said one of the young kiai Raudlatul Iman, Kiai Faisol, currently the prominent, well-known, and well-known of Raudlatul Iman is no longer his islamic boarding school but the formal education institutions in this islamic boarding school. Now, what the public first reads from Raudlatul Iman is early childhood education, playground, Islamic Elementary School, islamic junior high school, Islamic senior high school, Vocational Schools, and the Raudlatul Iman College of Da'wah (STIDAR), only after that the islamic boarding school (Faisol Aziz, interview, 17 September 2018).

Since the establishment of formal education (namely early childhood education, playground, Islamic Elementary School, islamic junior high school, Islamic senior high school, Vocational Schools, and the Raudlatul Iman College of Da'wah (STIDAR) since then also slowly diniyah, sorogan, and bandongan education at the Raudlatul Iman Islamic Boarding School have been less desirable by the students. Diniyah education becomes a second class for Raudlatul Iman students. According to one of the Islamic senior high school Raudlatul Iman teachers, who happened to also teach in diniyah, stating that the Raudlatul Iman students, both those who were faithful and those who were bats, considered religion schoolas an additional activity of education after formal education. For them, formal school is the most important while the islamic school is less important (Moh. Sa'di, interview, 17 September 2018).

When researchers conducted observations and interviews with several Raudlatul Iman teachers from the level of Islamic Elementary School, islamic junior high school, Islamic senior high school, Vocational Schools, researchers found facts, which this fact confirms that formal education is more urgent than religion education. This indication can be seen from the teaching and learning process that occurs. The teaching and learning process between formal schools and islamic school 
has a significant gap and discouraging us to see it. The teaching and learning process / education process in formal schools runs as public schools in general, the lessons take place in the classroom - with a modern teaching system, supported by rather adequate facilities such as the availability of laboratories, libraries, and other facilities provided by teacher. Meanwhile, when looking at the teaching and learning process at the islamic school, it seems to work as it is because it is not supported by complete physical facilities, for example the lack of classrooms and the absence of libraries. which forces teaching staff to buy themselves. What makes us sad, the teaching and learning that takes place is done instantly because of the lack of preparation from the teaching staff. Finally, what happens is that the teaching and learning process goes as it is, according to the wishes of the teaching staff / cleric.

Looking at the facts above, it shows that this problem should not be allowed to roll too long, because of fear of being a snowball which can threaten the existence of religion school specifically, and islamic boarding school in general. The problem of scientific integration must be taken seriously by reforming both the curriculum and the education process. Why is this important matter responded quickly by the islamic boarding school stakeholders, especially by the kiai as islamic boarding school authority holders, so that the negative implications of scientific integration can be minimized, even if it can be prevented. Because with this effort, the Islamic boarding school Raudlatul Iman will become a islamic boarding school of the hope of millennial society, will become the ideal islamic boarding school islamic boarding school of the future. Of course, to reach that level is not easy, there must be a concrete improvement or evolution of the islamic boarding school.

Raudlatul Iman Islamic Boarding School has led to the above goal. This indication shows that the researchers took corrective steps taken by the islamic boarding school caregivers. He began from improving the islamic boarding school curriculum, how the islamic boarding school curriculum and formal education curriculum were integrated correctly and appropriately so that negative implications such as the above could be prevented.

There are several corrective steps that will be taken by the kiai related to improving scientific integration in this islamic boarding school, namely by improving the islamic boarding school curriculum and formal education simultaneously, so that a connection between the two is established. With the improvement and improvement of this curriculum it can indirectly improve the quality of islamic boarding school and improve the quality of students (Farid Hasyim, 2013: 3 ). And to achieve that, a curriculum model that is able to formulate all educational actions towards scientific integration is needed. Speaking of curriculum models, it means that islamic boarding school want to open their eyes to find suitable curriculum models related to the integration of islamic boarding school scholarship. In this case, the kiai conducts the development of the islamic boarding school curriculum. Because in fact, the development of this curriculum aims to achieve the desired goals of islamic boarding school education, namely the integration of the curriculum and the achievement of the target of islamic boarding school education (Farid Hasyim, 2013: 66). The concept of islamic boarding school curriculum development includes three things, namely, first, the construction of the curriculum, which begins with the strengthening of curriculum ideas, where islamic boarding school stakeholders hold answers to the problem of islamic boarding school education. After the curriculum idea was felt to be mature enough, then proceeded to identify which curriculum model was most suitable for the islamic boarding school. 
Second, the implementation of the curriculum by involving all parties, how the curriculum model that has been chosen is implemented by all stakeholders (kiai, educators) of islamic boarding school and formal education institutions under the auspices of the Raudlatul Iman islamic boarding school. The implementation of this curriculum occupies a very important role, because it is a measure of whether the curriculum has been implemented or not. The most urgent thing from the implementation of the curriculum is that in implementing the curriculum the educator must refer to the integration of science, because in this way it can gradually eliminate the scientific dichotomy of the students. In addition, the implementation of the curriculum in the form of teaching and learning must be in accordance with the curriculum. If in this phase all parties carry out their duties properly, the curriculum implementation can be said to be successful.

Third, evaluation of the curriculum. This curriculum evaluation actually starts from the initial development of curriculum ideas, curriculum implementation, until the curriculum produces output. The question of whether the integration of the islamic boarding school curriculum reaches the target or cannot be seen from this third stage, evaluation (Dinn Wahyudin, 2014: 7).

Development of the islamic boarding school curriculum, said Kiai Sahli, is first, it is hoped that later it will be able to restore the image of Islamic boarding school Raudlatul Iman as a islamic boarding school to make ulama, kiai, and clerics who have the depth of Islamic scholarship, as before. Because before and before this islamic boarding school adopted the general knowledge curriculum, the Raudlatul Iman Islamic boarding school only focused on mastering the yellow book. Second, curriculum development is carried out to strengthen the foundations of Islamic science, more precisely students have strong mastery in the science of tools such as science nahwu, sorof, balaghah, interpretation, fiqh, and others. This image will be returned by the caregiver. And to achieve that target, the development and evaluation of the islamic boarding school curriculum is important to be done immediately. In line with the development of the islamic boarding school curriculum, later the islamic boarding school will introduce several programs related to the teaching of the yellow book, for example the yellow book course program, a special mentoring program to read the yellow book. The first program in its realization, all students were required to take the yellow book course intensely guided by local tutors and tutors who were intentionally brought in from other Salaf boarding schools. While the mentoring program specifically reads the yellow book is also addressed to all students but alternately and follow a predetermined schedule, for example one companion accompanies a maximum of 10 students. This accompaniment is temporary because if the students have mastered the science of tools, mentoring is considered complete, and other students are replaced, and so on (Sahli Hamid, interview, 18 September 2018).

\section{Conclusions and Recommendations}

The gap between the science of religion and science that occurred in Islamic boarding school Raudlatul Iman as an implication of scientific integration, where initially to eliminate the scientific dichotomy between the two. The scientific integration carried out by this islamic boarding school which was embodied through curriculum integration was originally intended so that the islamic boarding school still existed and its students were recognized as the same as educators from formal schools. However, apparently these ideals have a negative impact, because what happens is the erosion of Islamic scholarship. Islamic sciences that have long been developed in islamic boarding 
school are increasingly eroded because of lack of interest by students -students, a phenomenon that should not be allowed.

Seeing the above phenomenon, through the leadership of Kiai Sahli Hamid with the help of several other kiai and clerics, made a breakthrough in the form of concrete steps, namely strengthening scientific integration in islamic boarding school by developing and strengthening the implementation of islamic boarding school curriculum, creating a yellow book reading program, mentoring program read the yellow book, and improve the islamic boarding school organization.

\section{References}

[1] A.F. Stoner, James, dan Charles Wankel. Manajemen, Jakarta: CV. Intermedia, 1986.

[2] Dhofier, Zamakhsyari. Tradisi Islamic boarding school: Studi tentang Pandangan Hidup Kiai, Jakarta: LP3ES, 1982.

[3] Halim Soebahar, Abd. Modernisasi Islamic boarding school: Studi Transformasi Kepemimpinan Kiai dan Sistem Pendidikan Islamic boarding school, Yogyakarta: LKiS, 2013.

[4] Hasyim, Farid. Kurikulum Pendidikan Agama Islam, Malang: Madani, 2015.

[5] Kartanegara, Mulyadhi. Integrasi Ilmu: Sebuah Rekonstruksi Holistik, Jakarta: UIN Press, 2005.

[6] Ma'mur Asmani, Jamal. Peran Islamic boarding school dalam Kemerdekaan dan Menjaga NKRI, Yogyakarta: Aswaja Pressindo, 2016.

[7] Rivai Zainal, Veithzal, dkk. Kepemimpinan dan Perilaku Organisasi, Jakarta: PT. Rajagrafindo Persada, 2017.

[8] Suharto, Babun. Pondok Islamic boarding school dan Perubahan Sosial: Studi Transformasi Kepemimpinan Kiai Islamic boarding school, Yogyakarta: Pustaka Ilmu, 2018.

[9] Suheri, S., \& Nurrahmawati, Y. T. (2018). Model Pendidikan Multikultural Di Pondok Pesantren. Pedagogik: Jurnal Pendidikan, 5(1), 32-49.

[10] Suheri, S., \& Nurrahmawati, Y. T. (2018, April). Desain Pendidikan Multikultural di Pondok Pesantren Salaf Kauman Alhasani Allathifi Bondowoso. In PROCEEDINGS: Annual Conference for Muslim Scholars (No. Series 2, pp. 663-672).

[11] Suheri, S. (2017, May). Adversity Quotient di Pesantren. In PROCEEDINGS: Annual Conference for Muslim Scholars (No. Seri 2, pp. 591-597).

[12] Wahyudin, Dinn. Manajemen Kurikulum, Bandung: PT. Remaja Rosdakarya, 2014.

\footnotetext{
*Corresponding author.

E-mail address: suheri.lpdp@ gmail.com
} 